\title{
Newcastle students raise money for cancer charity
}

Dental students from Newcastle University have raised $£ 4,800$ for a local cancer charity.

DentSoc, a university society run by a committee of ten fourth year dental students, chose the Northern Head \& Neck Cancer Fund (HANC), based at Newcastle's Freeman Hospital, to be this year's nominated charity benefiting from their annual charity auction.

DentSoc organises social and charity events for the dental school throughout the year and in their popular annual auction, DentSoc committee and staff members donate services and prizes which are then bid for by dental students. These prizes range from anything from weekends away to extra revision sessions.

The HANC Fund aims to heighten awareness of head and neck cancer in the northern region and to enable faster detection and early stage treatment.

Nicola Perry, Stage 4 BDS student and President of DentSoc, was delighted at the amount raised through the charity auction and additional fundraising events and said: 'As dental students, head and neck cancer is very close to our hearts and I am delighted that we were able to raise such a significant amount for HANC. Hopefully, this donation will help the charity in their journey to raise awareness of this disease

\section{Ben Fund thanks its supporters at AGM}

This year's BDA Benevolent Fund Annual General Meeting was held on 17 June at the British Dental Association's headquarters in London.

Chaired by BDA President and Fund Patron, Dr Stuart Johnston, the meeting was an opportunity to thank industry supporters and outline future plans.

In 2015/16 the Benevolent Fund focussed on raising awareness, developing a new website, Facebook page and modern marketing materials to help spread the word.

The Officers of the Fund were re-elected, with Dr Ann Rockey named Chairman, Dr Bill Nichols as Vice-Chairman, Professor Ros Keeton named Honorary Treasurer and Mr Allan Franklin as Honorary Secretary.

The charity paid tribute to Dr John Turner who stood down as Trustee representing the Western Counties Branch after serving on the Board for over 30 years. Thanks were also given to Dr Raj Dhaliwal representing Central Counties Branch, who helped raise over $£ 9,000$ in the last two years and recently resigned from the Board. Express thanks were also given to Dr Dianne Waller (North Western) and Dr Michelle Slater (Community Dental Services) for their support and the Trustees wished them well in their retirement.

Providing assistance to UK dentists and their families in need, the charity provided grants and loans totalling over $£ 160,000$ in 2015 .

Dependent on the generosity of the profession, the BDA Benevolent Fund would like to thank all its supporters.

For more information visit www.bdabenevolentfund.org.uk. If you or a colleague you know are in need of help, call 02074864994.

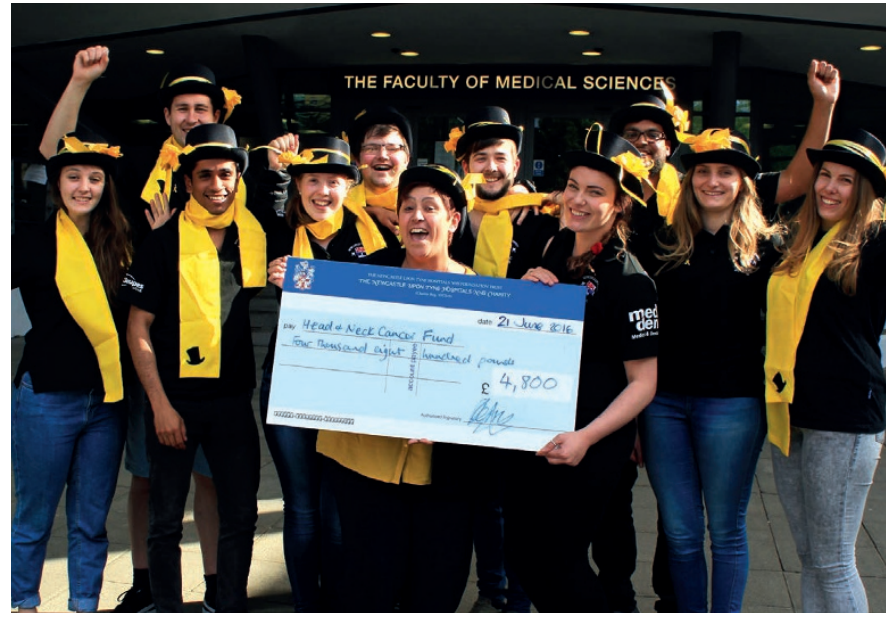

Fundraisers from DentSoc with Evelyn Weightman, BEM founder of HANC

and help to better the lives of those diagnosed. As president, I am extremely proud of the generosity of all students and staff of the dental school. We will continue to raise money throughout the year!'

http://www.northernhanc.org/

\section{Honours, awards, appointments}

Distinguished scientist award

Professor Tim Newton of King's College London's Dental Institute has been announced as the recipient of the IADR Distinguished Scientist Award for Behavioral, Epidemiologic and Health Services Research. This award, one of the highest honours bestowed by the IADR, recognises Professor Newton as a highly influential scientist in psychology as applied to dentistry and for his life-long achievements in the field.

\section{DTA President}

James Green has been elected the ninth president of the Dental Technologists Association (DTA), the professional representative body for dental technologists in the UK. James is currently a maxillofacial and dental laboratory manager for London's Great Ormond Street Hospital for Children and the North Thames Cleft Centre, a supra-regional network for patients with clefts of the lip and palate from North London, Essex and South and West Hertfordshire. This service is run jointly by Great Ormond Street and the St Andrew's Centre for Plastic Surgery at Broomfield Hospital near Chelmsford so he also works there for part of the time.

New board members

The Faculty of General Dental Practice (UK) has sworn in five new board members: Mark Richardson, Ian Mills, Johanna Bryant, Reena Wadia, and Pankaj Patel. The two new women on the board take the number up to three. Pankaj Patel represents the Faculty's 300 overseas members for the first time. 